\title{
Estudo Comparativo de Técnicas de Abordagem na Laqueadura Tubária: Microlaparoscopia
}

\section{Versus Minilaparotomia}

\author{
Comparative Study of Techniques to Perform Tubal Ligation: Micro-Laparoscopy Versus Minilaparotomy
}

Autor: Waldir Pereira Modotte

Orientador: Prof. Dr. Rogério Dias

Tese de Doutorado apresentada à Faculdade de Medicina de Botucatu, Universidade Estadual Paulista, em 27 de abril de 2004.

A contracepção cirúrgica voluntária definitiva (CCVD) é o método contraceptivo mais empregado em nosso meio e no mundo, sendo as vias minilaparatômica e laparoscópica as mais comuns, porém, é possível realizá-la com técnicas de microlaparoscopia, sob anestesia local e sedação consciente. O objetivo desse trabalho foi comparar a laqueadura realizada pela via microlaparoscópica, sob anestesia local e sedação consciente (Grupo I) com a via minilaparotômica sob bloqueio raquimedular (Grupo II). Vários parâmetros foram analisados nas amostras, sendo avaliadas estatisticamente, considerando valores de $\mathrm{p}<0,05$ como significativos. O Grupo I apresentou tempo para a realização total do procedimento menor que o Grupo II (43 minutos contra 57 minutos, $\mathrm{p}<0,05$ ), tempo para a realização do procedimento propriamente dito muito menor $(6,48$ minutos contra 30,32 minutos, $p<0,05)$ e tempo de permanência hospitalar inferior $(9,90$ horas contra 41,7 horas, $\mathrm{p}<0,05)$. A minilaparotomia apresen- tou maior número de morbidade, sendo a dor no local da incisão a queixa mais freqüente. Para avaliar o grau de satisfação e do efeito estético foram pontuados valores numéricos para as respostas ótimo, bom, regular, ruim e péssimo. A microlaparoscopia apresentou maior grau de satisfação $(\mathrm{p}<0,05)$ e melhor efeito estético em relação a minilaparotomia $(p<0,05)$. O custo direto padrão, avaliados a partir dos procedimentos realizados, utilizando metodologia de custo hospitalar padrão de procedimento, da microlaparoscopia foi $\mathrm{R} \$$ $109,30 /$ caso inferior. A laqueadura tubária pela via microlaparoscopica, sob anestesia local e sedação consciente apresenta vantagens sobre a minilaparotômica, podendo ser mais amplamente empregada nos centros de planejamento familiar.

Palavras-chave: Esterilização tubária. Laparoscopia. Anticoncepção.

$\mathrm{RBCO}$ $26(7): 584,2004$

\section{Polimorifismos Genéticos na Pré-Eclâmpsia}

\section{Gene Polymorphisms in Preeclampsia}

Autora: Adriani Oliveira Galão

Orientadores: Profa. Dra. Bartira Ercília Pinheiro da Costa Prof. Dr. Carlos Eduardo Poli de Figueiredo Profa. Dra. Rosane Machado Scheibe

Tese de Doutorado apresentada à Pontifícia Universidade Católica do Rio Grande do Sul, Curso de Pós-Graduação em Medicina e Ciências da Saúde (Área de Concentração: Nefrologia), em 31 de março de 2004.

Objetivo: avaliar quatro polimorfismos genéticos em mulheres grávidas com e sem pré-eclâmpsia.

Pacientes e Métodos: foram estudadas quarenta e uma mulheres com pré-eclâmpsia e sessenta gestantes normotensas. Pré-eclâmpsia foi definida como hipertensão arterial e proteinúria patológica em mulheres grávidas depois de 20 semanas de gravidez. O DNA foi obtido de leucócitos por digestão com Proteinase K, seguida por extração fenólica. O genótipo da sintase do óxido nítrico endotelial (eNOS) foi determinado por amplificação, por reação em cadeia da polimerase (PCR), seguido por digestão com enzima de restrição BanII. O polimorfismo de inserção/deleção no íntron 16 do gene da enzima conversora da angiotensina (ECA) foi detectado em amostras de DNA usando PCR. Para determinar o genótipo M235T do angiotensinogênio (AGT) realizamos PCR, seguido por digestão com enzima de restri- ção SfaNI. O genótipo C677T da metilenotetra-hidrofolato redutase (MTHFR) foi determinado por amplificação de PCR, seguido por digestão com enzima de restrição HinfI. $O$ teste de Qui-quadrado, $t$ de Student e regressão logística foram usados para a análise estatística.

Resultados: nenhuma diferença estatisticamente significativa na distribuição dos genótipos da eNOS, ECA, AGT e MTHFR, entre pré-eclâmpticas e grávidas normotensas, foi encontrada. Também nenhuma diferença estatisticamente significativa na freqüência alélica foi detectada.

Conclusões: os resultados não mostraram associação entre os polimorfismos genéticos da eNOS, ECA, AGT e MTHFR e o desenvolvimento de pré-eclâmpsia.

Palavras-chave: Hipertensão. Gravidez de alto-risco. Sistema renina-angiotensina. Marcadores genéticos. 